\title{
ResearchArticle
}

\section{Studies on genetic variability, heritability and genetic advance for quantitative characters in field pea}

\author{
Vaibhav Singh, Shweta, Anjali Singh and Geeta Rai
}

\section{SUMMARY}

The fifty genotypes of field pea were studied out during Rabi 2015-2016 and 2016-17 at Oilseed Research Farm, Kalyanpur of Chandra Shekhar Azad University of Agriculture and Technology, Kanpur (U.P.). The experiment was laid in a Randomized Complete Block Design with three replications for days to 50\% flowering, days to maturity, plant height, number of primary branches, number of nodes per plant, pod length, number of seed per pod, 100 seed weight, number of pod per plant and seed yield per plant.Analysis of variance showed significant differences among all the genotypes under study. The phenotypic co-efficient of variation was higher than genotypic co-efficient of variation for all the characters indicating the effect of environment on these characters. Studies of variation indicated that considerable amount of variation in plant height, number of pod per plant, number of nodes per plant, pod length and number of 100 -seed weight which could be utilized for breeding for improvement. All traits showed high heritability except number of primary branches per plant $(13 \%)$ and number of seeds per pod (18\%).The higher genetic advance showed in plant height.

Key Words : Genetic variation, Heritability, Genetic advance

How to cite this article : Singh, Vaibhav, Shweta, Singh, Anjali and Rai, Geeta (2018). Studies on genetic variability, heritability and genetic advance for quantitative characters in field pea. Internat. J. Plant Sci., 13 (1): 93-97, DOI: 10.15740/HAS/IJPS/13.1/93-97.

Article chronicle : Received : 10.10.2017; Revised : 21.11.2017; Accepted : 05.12.2017

MEMBERS OF THE RESEARCH FORUM

Author to be contacted :

Vaibhav Singh, Department of Genetics and Plant Breeding, Chandra Shekhar Azad University of Agriculture and Technology, Kanpur (U.P.) India

Address of the Co-authors:

Shweta, Anjali Singh and Geeta Rai, Department of Genetics and Plant Breeding, Chandra Shekhar Azad University of Agriculture and Technology, Kanpur (U.P.) India 